\title{
Diet of the coati Nasua nasua (Carnivora: Procyonidae) in an area of woodland inserted in an urban environment in Brazil
}

\author{
Dieta del Coatí Nasua nasua (Carnivora: Procyonidae) en un fragmento de bosque dentro \\ en un ambiente urbano en Brasil \\ GIOVANNE A. FERREIRA ${ }^{1,2 *}$, EDUARDO NAKANO-OLIVEIRA ${ }^{2,3}$, GELSON GENARO ${ }^{2,4}$, \\ \& ADMA K. LACERDA-CHAVES 5 \\ ${ }^{1}$ Programa de Pós Graduação em Biologia e Comportamento Animal, Universidade Federal de Juiz de Fora, Campus \\ Universitário/sn, Juiz de Fora, MG, 36036-900, Brasil \\ ${ }^{2}$ Instituto de Pesquisas Cananéia. Rua João Salim, Lote 26, Quadra Y, Parque Xangrilá, Campinas, SP, 13098-106, Brasil \\ ${ }^{3}$ Conselho Nacional de Defesa Ambiental, CNDA, Rua Dr. Renato Paes de Barros, 512 conj. 131, \\ São Paulo, SP, 04530-000, Brasil \\ ${ }^{4}$ Programa de Pós-Graduação em Psicobiologia da Faculdade de Filosofia Ciências e Letras de Ribeirão Preto da Universidade \\ de São Paulo, Ribeirão Preto, SP, 14001-970, Brasil \\ ${ }^{5}$ Instituto de Ciências Ambientais e Desenvolvimento Sustentável, Universidade Federal da Bahia, Av. Prof. José Seabra, \\ S./N. Centro, Barreiras, BA, 47800-000, Brasil \\ ${ }^{*}$ Corresponding author: ferreira.g.a@hotmail.com
}

\begin{abstract}
Coatis are omnivores whose diet consists of small vertebrates, invertebrates, and fruit. In urban areas, they may ingest food waste that has been discarded in deposits near their habitat, or they may consume food offered by humans. The present work investigates the diet of coatis through analysis of 56 fecal samples collected from Morro Imperador, a fragment of woodland inserted into an urban center in the municipality of Juiz de Fora, State of Minas Gerais, Brazil. The results point to a diet with niche breadth of 0.4 in which the percentage of occurrence of insects (34.9\%) and fruit $(19.9 \%)$ comprise the main dietary items. The presence of food due to human action (direct or indirect) is also constant throughout the year (14.1\%), thereby demonstrating the ability of these animals to adapt to modified environments.
\end{abstract}

Key words: anthropic influence, Atlantic Forest, diet alteration, trophic ecology.

\section{RESUMEN}

Los coatíes son omnívoros cuya dieta se compone de pequeños vertebrados, invertebrados y frutas. En zonas urbanas, pueden ingerir residuos de alimentos provenientes de desechos domésticos próximos a su hábitat, como también alimentos ofrecidos por seres humanos. El presente trabajo investiga la dieta de coatíes a través del análisis de 56 muestras de heces colectadas en el Morro Imperador, un fragmento de bosque incluido en una área urbana del municipio de Juiz de Fora, Estado de Minas Gerais, Brasil. Los resultados indican una dieta con amplitud de nicho de 0,4 siendo que, en que la porcentaje de ocurrencia de insectos (34.9\%) y frutas (19.9\%) constituyen los principales componentes alimentarios. La presencia de alimentos debido a la acción humana (directa o indirecta) también es constante durante todo el año (14.1\%), lo que demuestra la capacidad de adaptación de estos animales en ambientes modificados.

Palabras clave: alteraciones alimentarias, ecología trófica, influencia antropogénica, Mata Atlántica.

\section{INTRODUCTION}

The continuous fragmentation of the Brazilian woodland known as Mata Atlântica (Atlantic Forest), together with the ever-increasing anthropic occupation of this biome, has culminated in diminished areas for animals to explore. As a result, animals living in these regions have had to turn to new approaches to find food. However, when wild animals leave the woodland to search for domestic food, they may undergo behavioral changes and be exposed to anthropic aggression.

The Procyonidae species are distributed throughout America. Among the species of 
the genus Nasua, the white-nosed coati, Nasua narica (Linnaeus, 1766), mainly inhabits Central America, while the common coati, $N$. nasua (Linnaeus, 1766), inhabits South America. The common coati has been less intensively sutided than the white-nosed coati (Gompper \& Decker 1998).

Coatis are diurnal animals with arboreal habits (Redford \& Stearman 1993, Gomper \& Decker 1998, Cheida et al. 2011). They forage using their long mobile snouts, which are adapted to the investigation of cracks and holes. Coatis feed on small vertebrates, invertebrates, and fruit (Bisbal 1986, Mc Clearn 1992, Beisiegel 2001), but they can also ingest food waste discarded in deposits in urban regions that are close to the areas that they occupy (Alves-Costa et al. 2004).

The present investigation aimed to evaluate the diet of coatis living in a fragment of the Mata Atlântica in the urban area of the municipality of Juiz de Fora, state of Minas Gerais, Brazil. Fecal samples were gathered from a coati population inhabiting this area and were analyzed. The possible anthropic influence on the diet of these animals was also assessed. This investigation tests the hypothesis that the coati is a generalist and opportunistic species regarding its choice of plants, animals, and the use of food from anthropogenic origin.

\section{METHODS}

\section{Study Area}

The municipality of Juiz de Fora has a total area of 1,424 $\mathrm{km}^{2}$ and is located in the southeast of the state of Minas

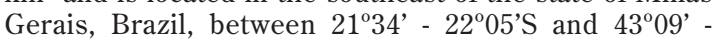
$43^{\circ} 45^{\prime} \mathrm{W}$. Its minimum and maximum altitudes are 467 $\mathrm{m}$ and $1104 \mathrm{~m}$, respectively. According to the Köppen climate classification, the municipality has Cwa and Cwb climates (highland tropical climate with hot summers). The average annual temperature is approximately 22.5 ${ }^{\circ} \mathrm{C}$, and the average annual precipitation is $1470 \mathrm{~mm}$ (LabCAA 2006).

The woodland fragment known as Mata do Morro do Imperador is situated between coordinates $21^{\circ} 45^{\prime} 13^{\prime}$ - $21^{\circ} 46^{\prime} 13^{\prime \prime} \mathrm{S}$ and $43^{\circ} 21^{\prime} 19^{\prime \prime}-43^{\circ} 22^{\prime} 15^{\prime \prime} \mathrm{W}$. It is an area consisting of a mosaic of fragments totaling 78 ha of secondary forest; Mata do Morro do Imperador reaches an altitude of $923 \mathrm{~m}$, one of the highest points in the city. According to Sato (1995), this area is classified as Seasonal Semi-deciduous Mountain Forest, a subdivision of the biome Mata Atlântica. It is one of the remaining fragments of this type of woodland in Juiz de Fora, localized in a central area of the city that is comprised of private land as well as public areas belonging to the municipal government.

\section{Collection and analysis of data}

Visits to the area of Mata do Morro do Imperador for collection of samples of coati feces were organized every 14 days over a period of 24 months. Mapped areas along tracks, forest borders, and places where these animals had been seen foraging were covered in an attempt to locate and extract the largest possible number of samples.

Initially, the fecal samples were individually stored in labeled plastic bags. Later, they were placed in jars with lids containing AFA solution (ethanol, $70^{\circ} \mathrm{GL}, 90 \mathrm{~mL}$; formaldehyde, $5 \mathrm{~mL}$; acetic acid $2 \mathrm{~mL}$ ) for preservation and further analysis. In the laboratory, the samples were washed in thin-mesh sieves $(0.5 \mathrm{~mm})$ and dried under sunlight for 48 to 72 hours. Items were separated and grouped into ten categories for analysis: (1) mammals, (2) birds, (3) reptiles, (4) amphibians, (5) other items of vertebrate origin (such as egg shells), (6) arachnids, (7) insects, (8) plants, (9) domestic food, and (10) waste (nondigestible material of anthropic origin, including but not limited to plastic, paper, and Styrofoam).

Slides for identification of hair cuticles and medulla microstructures were mounted using material from the samples in order to identify items classified under "mammals" (Quadros 2002, Quadros \& Monteiro-Filho 2006). This technique aided identification of dietary species and confirmed that the defecating species was really the target species. This analysis was carried out via comparison with samples reported in the specialized literature (Quadros 2002, Martin et al. 2009). For the items in categories 2-10 above, comparison with samples previously collected in the study area and collaboration with other specialists enabled us to characterize the samples to the lowest taxonomic level possible.

To determine the importance of each food item for the diet of coatis, the percentage of occurrence (PO) of each item was calculated by dividing its total frequency by the sum of the frequencies of all other items (Maehr \& Brandy 1986). To quantify how common a specific item was, we computed the frequency of occurrence (FO), which corresponds to the percentage of each feces containing this item (Konecny 1989).

The degree of diet specialization was estimated on the basis of the niche breadth as judged from the standardized Levins index $\left(\mathrm{B}_{\mathrm{A}}\right.$; range 0 to 1 ; values near or equal to 1.0 indicate a higher niche amplitude). For this estimation, dietary categories 1-9 were considered; materials classified as "waste" (category 10) were considered to have been ingested accidentally while the animals were foraging, and thus they were not included in the diet specialization analysis.

\section{RESULTS}

A total of 56 fecal samples were collected, 22 during the dry season (39.3\%; $\mathrm{n}=10$ during the first 12 months of collection (Year I) and $n$ $=12$ during the second 12-month period (Year II)) and 34 during the rainy season (60.7 \%; $\mathrm{n}=$ 13 during Year I and $\mathrm{n}=21$ during Year II). The average number of food items per feces was 4.5 (minimum of 1 and maximum of 10). Fifty taxa were identified in the diet of $N$. nasua (Table 1). 
TABLE 1

Food items detected in the feces from $N$. nasua living in a fragment of the Mata Atlântica. FO = frequency of occurrence; $\mathrm{PO}=$ percentage of occurrence; n.i. = not identified

Componentes alimentarios detectados en las heces de $N$. nasua en un fragmento de la Mata Atlántica. FO = frecuencia de ocurrencia; $\mathrm{PO}=$ porcentaje de ocurrencia; n.i. = no identificado.

\begin{tabular}{|c|c|c|}
\hline \multirow{2}{*}{ Food items } & \multicolumn{2}{|c|}{$\begin{array}{c}\text { Total } \\
(\mathrm{N}=56)\end{array}$} \\
\hline & FO & $\mathrm{PO}$ \\
\hline \multicolumn{3}{|l|}{ Vertebrates } \\
\hline Mammals & 41.1 & 9.5 \\
\hline Didelphimorfia: Didelphidae: Gracilinanus sp. & 1.8 & 0.4 \\
\hline Rodentia: Cricetidae: Calomys tener (Winge, 1887) & 10.7 & 2.5 \\
\hline Rodentia: Cricetidae: Akodon sp. & 5.4 & 1.2 \\
\hline Rodentia: Cricetidae: Oligoryzomys sp. & 7.1 & 1.7 \\
\hline Rodentia: Cricetidae: Oxymycterus sp. & 1.8 & 0.4 \\
\hline Rodentia: Muridae: n.i. & 14.3 & 3.3 \\
\hline Aves & 21.4 & 5.0 \\
\hline Passeriforme: n.i. & 19.6 & 4.6 \\
\hline Birds: n.i. & 1.8 & 0.4 \\
\hline Reptiles & 8.9 & 2.1 \\
\hline Squamata: Colubridae & 3.6 & 0.8 \\
\hline Squamata: Anguidae & 5.4 & 1.2 \\
\hline Amphibians & 14.3 & 3.3 \\
\hline Anura: Hylidae: n.i. & 14.3 & 3.3 \\
\hline Other & 10.7 & 2.5 \\
\hline Eggs & 10.7 & 2.5 \\
\hline \multicolumn{3}{|l|}{ Invertebrates } \\
\hline Arachnids & 7.1 & 1.7 \\
\hline Aranea: Araneomorpha & 5.4 & 1.2 \\
\hline Aranea: Opiliones & 1.8 & 0.4 \\
\hline Insects & 100.0 & 34.9 \\
\hline Blattaria: Blatidae & 26.8 & 6.2 \\
\hline Coleoptera: Scarabaeidae & 5.4 & 1.2 \\
\hline Coleoptera: Carabidae & 7.1 & 1.7 \\
\hline Coleoptera: Passalidae & 3.6 & 0.8 \\
\hline Coleoptera: n.i. & 1.8 & 0.4 \\
\hline Orthoptera: Acrididae & 5.4 & 1.2 \\
\hline Orthoptera: Tettigoniidae & 7.1 & 1.7 \\
\hline
\end{tabular}




\begin{tabular}{|c|c|c|}
\hline \multirow[t]{2}{*}{ Food items } & \multicolumn{2}{|c|}{$\begin{array}{c}\text { Total } \\
(\mathrm{N}=56)\end{array}$} \\
\hline & $\mathrm{FO}$ & $\mathrm{PO}$ \\
\hline Orthoptera: Grillacrididae & 3.6 & 0.8 \\
\hline Orthoptera: Gryllidae & 5.4 & 1.2 \\
\hline Orthoptera: n.i. & 5.4 & 1.2 \\
\hline Hymenoptera: Vespidae & 3.6 & 0.8 \\
\hline Hymenoptera: Formicidae & 8.9 & 2.1 \\
\hline Hymenoptera: Apidae & 3.6 & 0.8 \\
\hline Hemiptera: Heteroptera & 1.8 & 0.4 \\
\hline Lepidoptera: n.i. & 3.6 & 0.8 \\
\hline Odonata: Aeshnidae & 1.8 & 0.4 \\
\hline Isoptera: Termitidae & 3.6 & 0.8 \\
\hline Mantodea: n.i. & 1.8 & 0.4 \\
\hline Insets: n.i. & 50 & 11.6 \\
\hline Plants & 85.7 & 19.9 \\
\hline Aracales: Arecaceae: Syagrus romanzoffiana & 10.7 & 2.5 \\
\hline Ericales: Lecythidaceae: Lecythis pisonis & 7.1 & 1.7 \\
\hline Rosales: Moraceae: Ficus sp. & 8.9 & 2.1 \\
\hline Rosales: Urticaceae: Cecropia sp. & 7.1 & 1.7 \\
\hline Rosales: Rosaceae: Rubus sp. & 3.6 & 0.8 \\
\hline Myrtales: Myrtaceae: Psidium guayava & 5.4 & 1.2 \\
\hline Myrtales: Myrtaceae: Eugenia cerasiflora & 3.6 & 0.8 \\
\hline Vegetal material: n.i. & 39.3 & 9.1 \\
\hline Domestic food & 60.7 & 14.1 \\
\hline Animal food & 1.8 & 0.4 \\
\hline Fruit & 19.6 & 4.6 \\
\hline Cooked bones & 12.5 & 2.9 \\
\hline Other types of domestic food & 26.8 & 6.2 \\
\hline Waste & 30.4 & 7.1 \\
\hline Plastic & 16.1 & 3.7 \\
\hline Styrofoam & 3.6 & 0.8 \\
\hline Paper & 5.4 & 1.2 \\
\hline Aluminum foil & 1.8 & 0.4 \\
\hline Other & 3.6 & 0.8 \\
\hline Total occurrence of items & & $100 \%$ \\
\hline
\end{tabular}


Insects $(\mathrm{PO}=34.9 \%)$ and food of plant origin $(\mathrm{PO}=19.9 \%)$ were the main items in most of the examined samples. Insects were observed in feces collected in all surveyed months (Fig. 1; Table 1). The coatis ingested fruit belonging to seven species: queen palm (Syagrus romanzoffiana [(Cham.) Glassman,1968]), cream nut (Lecythis pisonis [Cambessèdes,1829]), fig trees (Ficus sp.), cecropias (Cecropia sp.), guava (Psidium guayava [Linnaeus, 1753]), blackberry (Rubus sp.), and fruit from Eugenia cerasiflora (Miquel 1849). When considered together with other unidentified plant fragments, these items were present in $85.7 \%$ of the fecal samples (Table 1). Domestic food (including animal food, fruit, and cooked bone) was detected in $60.7 \%$ of the analyzed feces, corresponding to $14.1 \%$ of the total number of items identified in the diet. Vertebrates were detected in $98.2 \%$ of the feces;

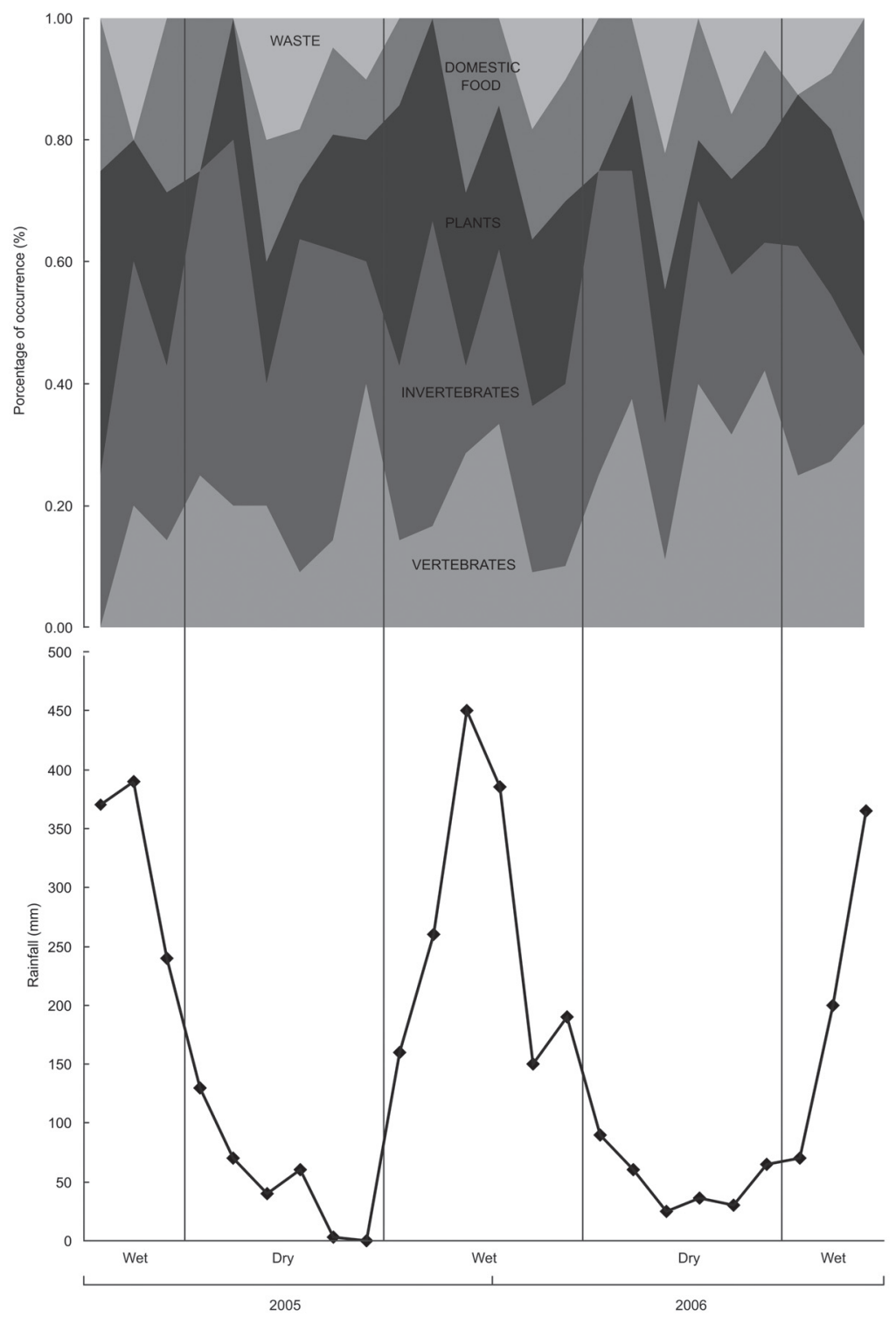

Fig. 1: Relationship between the items detected in the diet of coatis ( $N$. nasua; top panel) and the average monthly rainfall recorded between January of Year I and December of Year II (lower panel) in a fragment of the Mata Atlântica.

Relación entre los componentes detectados en la dieta de coatíes ( $N$. nasua; panel superior) y el promedio de lluvias mensuales registradas entre enero del año I y diciembre del año II (panel inferior) en un fragmento de la Mata Atlántica. 
mammals were the most consumed vertebrates $(\mathrm{PO}=9.5 \%)$, followed by birds $(\mathrm{PO}=5.0 \%)$, amphibians $(\mathrm{PO}=3.3 \%)$, and reptiles $(\mathrm{PO}=2.0$ $\%$; Table 1). Nondigestible material of anthropic origin ("waste") corresponded to $7.1 \%$ of the items and was found in $30.4 \%$ of the feces.

The trophic niche breadth analysis indicated a diet with values intermediate between those from a generalist diet and those from a specialist diet $\left(B_{A}=0.4\right)$.

\section{DISCUSSION}

There is a paucity of studies reporting the anthropic impact on the diet of coatis in natural areas (Alves-Costa et al. 2004, Hirsch 2009), especially in regions under large anthropic influence. One such region is Morro do Imperador, located in the urban center of the municipality of Juiz de Fora, Minas Gerais, Brazil.

Coatis inhabiting woodlands feed mainly on fruit, invertebrates, and small vertebrates (Emmons 1990, Mc Clearn 1992, Beisiegel 2001). Consistent with the observations of Bisbal (1986) and Alves-Costa et al. (2004), in our analysis invertebrates represented the major food source for coatis occupying the woodland in Morro do Imperador (Table 2 ). These invertebrates mainly consisted of blattaria, orthoptera, and coleoptera, which together accounted for $36.5 \%$ of the total number of items. Despite their small importance in terms of energy intake (relative to volume), these invertebrates were more frequently consumed over virtually the entire study period. Fruit was the second most ingested item and therefore represents an important part of the diet of coatis. Redford and Stearman (1993) and Santos and Beisiegel (2006) reported that fruit is the item that is most consumed by coatis (Table 2). In contrast to the findings of Alves-Costa et al. (2004), birds did not make up a very substantial portion of the coati diet, although birds were found in some of the analyzed samples. Rodents were the most frequently ingested mammals (9.6 $\%$ of the total of consumed items and $42.6 \%$ of the vertebrate items). The smaller intake of mammals during the rainy season may be related to the larger availability of fruit during this period, as reported by Alves-Costa et al. (2004) and Hirsch (2009).
Coatis were consistently spotted foraging on the margins of a highway crossing the woodland region of Morro do Imperador, where there is a kiosk that sells coconut water. Coatis were often seen removing the solid endosperm from inside the coconuts that had been deposited in cotton bags and placed near the kiosk for selective garbage collection. Moreover, customers of the kiosk, residents of the area surrounding the woodland, and students and staff of a school near the study area frequently offered industrialized food, such as bread and biscuits, to these animals. However, no evidence of these items was found in the analyzed fecal samples due to their complete digestion. Ingestion of blattaria, added to the "waste" detected in the samples, reinforces the notion of adaptive behavior by foraging coatis in natural areas under anthropic influence. These animals explore resources deposited in garbage bins (AlvesCosta et al. 2004), Hirsch 2009). Constant offers of industrialized food and consumption of food items that are easy to digest, such as solid coconut endosperm, as well as the absence of these items in the analyzed fecal samples suggest cautious interpretation of the coati diet based exclusively on feces analysis. This suggestion is corroborated by reports that these animals also feed on cultivated fruit (such as mango and guava) and on food that is directly provided to coatis living in situations of semi-captivity, for which there is no confirmation in fecal samples (Santos \& Beisiegel, 2006). Although a wide variety of items were detected in the samples, the niche breadth values for this region partly diverge from what has been suggested in terms of a generalist diet (Redford \& Stearman 1993). We calculated intermediate values closer to zero, which characterizes the target species as having a generalist diet.

Our observations demonstrate that coatis can use alternative food resources that are abundant and close to the area they explore, which may be interfering in their search for food within the woodland itself. It remains unverified whether the woodland in Morro do Imperador furnishes enough food throughout the entire year to sustain the coati population; a lack of natural resources would justify their inspection of other food sources. Opportunistic exploration of food waste deposits and 
TABLE 2

Frequency of occurrence of food items as reported in previous studies of $N$. nasua involving different methodologies. n.r. = values not reported, although indicated in the study. - items not mentioned in the study. ${ }^{a}$ stomach contents; ${ }^{b}$ direct observations; ${ }^{c}$ fecal analysis

Frecuencia de ocurrencia de los componentes alimentarios de $N$. nasua registrados en estudios anteriores con diferentes métodos. n.r. = valores no reportados, aunque se indica en el estudio. - ítems que no fueron mencionadas en el estudio. ${ }^{\mathrm{a}}$ contenido del estómago; ${ }^{\mathrm{b}}$ observación directa; ${ }^{\mathrm{c}}$ análisis de las heces.

\begin{tabular}{|c|c|c|c|c|c|c|c|}
\hline & $\begin{array}{c}\text { Bisbal } \\
1986^{\mathrm{a}} \\
\mathrm{n}=3\end{array}$ & $\begin{array}{c}\text { Redford \& } \\
\text { Stearman } \\
1993^{\mathrm{a}} \\
\mathrm{n}=11\end{array}$ & $\begin{array}{c}\text { Beisiegel } \\
2001^{\mathrm{b}} \\
\mathrm{n}=32\end{array}$ & $\begin{array}{l}\text { Alves-Costa } \\
\text { et al. } 2004^{\mathrm{c}} \\
\quad \mathrm{n}=226\end{array}$ & $\begin{array}{c}\text { Santos \& } \\
\text { Beisiegel } \\
2006^{\mathrm{c}} \\
\mathrm{n}=60\end{array}$ & $\begin{array}{l}\text { Hirsch } \\
2009^{\mathrm{b}} \\
\mathrm{n}=4648\end{array}$ & $\begin{array}{c}\text { This } \\
\text { article }^{\mathrm{c}} \\
\mathrm{n}=56\end{array}$ \\
\hline \multicolumn{8}{|l|}{ Vertebrates } \\
\hline Mammals & - & 40.0 & - & 0.9 & - & - & 41.1 \\
\hline Birds & - & - & - & 2.2 & - & $<0.1$ & 21.4 \\
\hline Reptiles & 33.0 & - & - & 0.9 & - & & 8.9 \\
\hline Amphibians & - & - & - & 0.4 & - & $<0.1$ & 14.3 \\
\hline Fish & - & - & - & 0.4 & - & $<0.1$ & - \\
\hline Eggs & - & - & - & 2.2 & - & & 10.7 \\
\hline $\begin{array}{l}\text { Unknown } \\
\text { vertebrates }\end{array}$ & & & n.r. & 2.2 & & & 10.7 \\
\hline \multicolumn{8}{|l|}{ Invertebrates } \\
\hline Arachnids & - & 30.5 & - & 36.6 & - & & 7.1 \\
\hline Insects & 100.0 & - & - & 75.7 & 13.5 & & 100.0 \\
\hline Millipedes & - & - & - & 53.9 & - & & - \\
\hline Crustaceans & - & - & - & - & 1.7 & & - \\
\hline Gastropods & - & - & - & 2.6 & - & & - \\
\hline $\begin{array}{l}\text { Unknown } \\
\text { invertebrates }\end{array}$ & 33.0 & - & n.r. & - & - & 80.0 & - \\
\hline Plants & 33.0 & 65.9 & 43.8 & 85.4 & 96.6 & 14.0 & 85.7 \\
\hline Domestic food & - & - & - & - & 31.6 & 5.0 & 60.7 \\
\hline Waste & - & - & - & 9.7 & - & n.r. & 30.4 \\
\hline
\end{tabular}

resources offered by humans have already been observed for other mammalian species such as tufted capuchins (Cebus sp.; Sabbatini et al. 2006, Sabbatini et al. 2008). This behavior can culminate in replacement of the natural diet with inappropriate food of low nutritional status, resulting in nutritional deficit. Moreover, the consumption of adulterated or poorly conserved anthropogenic items in food waste deposits can alter gastrointestinal function as well as compromise the immune system and general health of the animals (Sabbatini et al. 2006). This situation is worsened by intake of industrialized food or nondigestible materials such as plastic, paper, aluminum, and Styrofoam. It is worth highlighting that these wild animals are subject to aggression by humans and domestic animals and risk being hit by vehicles when they leave the forest in search for food.

Bearing in mind the role of seed dispersal in the maintenance of the majority of the plant species in tropical forests (Jazen 1980, CharlesDominique et al. 1986, Stoner et al. 2007), modifications in the coati feeding behavior may reduce its potential role as a seed disperser 
(Alves-Costa et al. 2004, Costa \& Mauro 2008). This scenario has also been documented by Sheldon (1992) in studies of the crab-eating fox (Cerdocyon thous [Linnaeus, 1766]).

The dynamics of these small fragments and the biology of the coati are little known and more detailed knowledge is necessary for planning management strategies. Mitigating actions are urgent and need to be promptly applied to preserve coatis as well as other vertebrates and to minimize the problems related to the interaction between humans and wild animals.

ACKNOWLEDGMENTS: We thank Instituto de Pesquisas Cananéia (IPeC), Universidade Presidente Antônio Carlos and the Federal University of Juiz de Fora for scientific and logistic support. We thank the researchers Desvaux JS and Gómez DE, for his contribution in reviews in the Spanish language. We also thank Coordenação de Aperfeiçoamento de Pessoal de Nível Superior - CAPES for the Master scholarship granted to G. A. F.

\section{LITERATURE CITED}

ALVES-COSTA CP, GAB FONSECA \& C CHRISTÓFARO (2004) Variation in the diet of the brown-nosed coati (Nasua nasua) in Southeastern Brazil. Journal of Mammalogy 85: 478-482.

BEISIEGEL BM (2001) Notes on the coati, Nasua nasua (Carnivora: Procyonidae) in an Atlantic forest area. Brazilian Journal of Biology 61: 689-692.

BISBAL FJ (1986) Food habits of some neotropical carnivores in Venezuela (Mammalia, Carnivora). Mammalia 50: 329-339.

LabCAA - Laboratório de Climatologia e Análise Ambiental (2006) Banco de Dados.

Departamento de Geociências, UFJF. Juiz de Fora, Brazil.

CHARLES-DOMINIQUE P, M ATRAMENTOWICZ, M CHARLES-DOMINIQUE, H GERARD, A HLADIK, CM HLADIK \& MF PRÉVOST (1981) Les mammifères frugivores arboricoles nocturnes d'une forêt guyanaise: Interrelations plantesanimaux. Revue d'Ecologie (la Terre et la Vie) 35: 341-435.

CHEIDA CC, E NAKANO-OLIVEIRA, R FUSCO-COSTA, F MENDES, \& J QUADROS (2011) Ordem Carnívora. In: Reis NR, AL Peracchi, WA Pedro \& IP Lima (eds) Mamíferos do Brasil: 231-275. Second edition, Londrina, Brazil.

COSTA EMJ \& RA MAURO (2008) Dispersão secundária em fezes de quatis Nasua nasua (Linnaeus, 1766) (Mammalia: Procyonidae) em um fragmento de Cerrado, Mato Grosso do Sul, Brasil. Neotropical Biology and Conservation (Brazil)3: 66-72.
EMMONS LH (1990) Neotropical rainforest mammals: A field guide. University of Chicago Press. Chicago, USA.

GOMPPER ME \& DM DECKER (1998) Nasua nasua. Mammalian Species 580: 1-9.

HIRSCH BT (2009) Seasonal Variation in the diet of ringtailed coatis (Nasua nasua) in Iguazu, Argentina. Journal of Mammalogy 90: 136-143.

JANZEN DH (1980) Ecologia vegetal nos trópicos. Vol. 7, EPU, Editora da Universidade de São Paulo, São Paulo, Brazil

KONECNY MJ (1989) Movement patterns and food habits of four sympatric carnivore especies in Belize, Central America. In: Redford. KH \& JF Eisenberg (eds) Advances in neotropical mammalogy: 243-264. The Sanshill Crane Press, Inc., Gainesville, USA.

MAEHR DS \& JR BRADY (1986) Food habits of bobcats in Florida. Journal of Mammalogy 67: 133-138.

MARTIN PS, C GHELER-COSTA \& LM VERDADE (2009) Microestruturas de pêlos de pequenos mamíferos não-voadores: chave para identificação de espécies de agrossitemas do estado de São Paulo, Brazil. Biota Neotropica 9: 233-241.

MC CLEARN D (1992) Locomotion, posture, and feeding behaviour of kinkajous, coatis, and racoons. Journal of Mammalogy 73: 245-261.

QUADROS J (2002) Identificação microscópica de pêlos de mamíferos brasileiros e sua aplicação no estudo da dieta de carnívoros. Ph. D. Thesis. Postgraduate Course in Biological Sciences, Universidade Federal do Paraná, Curitiba, Brazil.

QUADROS J \& ELA MONTEIRO-FILHO (2006) Coleta e preparação de pêlos de mamíferos para identificação em microscopia óptica. Revista Brasileira de Zoologia (Brazil) 23: 274-278.

REDFORD KH \& A M STEARMAN (1993) Notas sobre la biologia de tres procyonidos simpatricos bolivianos (Mammalia: Procyonidae). Ecología en Bolivia (Brazil) 21: 35-44.

SABBATINI G, M STAMMATI, MCH TAVARES, V GIULIANI \& E VISALVERGHI (2006) Interactions between humans and capuchin monkeys (Cebus libidinosus) in the Parque Nacional de Brasília, Brazil. Applied Animal Behaviour Science 97: 272-283.

SABBATINI G, M STAMMATI, MCH TAVARES, \& E VISALBERGHI (2008) Behavioral flexibility of a group of bearded capuchin monkeys (Cebus libidinosus) in the Parque Nacional de Brasilia (Brazil): consequences of cohabitation with visitors. Brazilian Journal of Biology 68: 685-693.

SANTOS VA \& BM BEISIEGEL (2006) A dieta de Nasua nasua (Linnaeus, 1766) no Parque Ecológico do Tietê, SP. Revista Brasileira de Zoologia (Brazil) 8: 199-203.

SATO J (1995) Mata Atlântica - Direito Ambiental e legislação. Ed. Hemus. São Paulo, Brazil.

SHELDON JW (1992) Wild dogs: the natural history of the nondomestic Canidae. Academic Press, Inc. San Diego, USA.

STONER KE, P RIBA-HERNÁNDEZ, K VULINEC \& JE LAMBERT (2007) The role of mammals in creating and modifying seedshadows in Tropical Forest and some possible consequences of their elimination. Biotropica 39: 316-327. 